such as the Explanatory Model Interview Catalogue (Weiss, 1997), which seek to validate cultural experience and psychopathology on its own terms, provide just that. They tease out the relationship between experience near (racism) and experience distant (psychiatric diagnoses) vocabularies, and help establish causal links between the two. This is the subject matter of medical anthropology and indeed a major research agenda for cultural psychiatry in the twenty-first century (Bibeau, 1997).

AMERICAN PSYChIATRIC Association (1994) Diagnostic and Statistical Manual of Mental Disorders (4th edn) (DSMIV). Washington, DC: APA.

BIBEAU, G. (1997) Cultural psychiatry in a creolising world-questions for a new research agenda. Transcultural Psychiatry, 34, 9-41.

GAINES, A. (1992) Ethnopsychiatry: the Cultural Construction of Professional and Folk Psychiatrles. New York: State University of New York Press.

HickuNG, F. W. \& HUTCHINSON, G. (1999) Roast breadfruit psychosis: a consequence of disturbed racial identification in African-Caribbeans. Psychiatric Bullettr. 23, 132-134.

JADHAV, S. \& LTTLEWOOD, R. (1994) Defeat Depression Campaign-Some Medical Anthropological Queries. Psychiatric Bulletin, 18, 572-573.

KIRK, S. A. \& KUTCHINS, H. (1992) The Selling of DSM - The Rhetoric of Science in Psychiatry. New York: Aldine De Gruyter.

LTTLEWOOD. R. (1985) Jungle Madness: some observations on expatriate psychopathology. International Joumal of Soctal Psychiatry. 31, 194-197.

ManNoNi. O. (1956) Prospero and Caliban - The Psychology of Colonisation (translation of 1948 French edition). New York: Praeger.

MorRISON. T. (1994) The Bluest Eye. London: Chatto and Windus.

WEISS, M. (1997) Explanatory Model Interview Catalogue (EMIC): Framework for comparattve study of illness. Transcultural Psychiatry, 34, 235-263.

WORLD HEALTH ORGanization (1992) The Tenth Revision of the International Classfication of Diseases and Related Health Problems (ICD-10). Geneva: WHO.

Young, A. (1995) The Harmony of Mlusions: Inventing PostTraumatic Stress Disorder. New Jersey: Princeton University Press.

Sushrut Jadhav, Founding Editor, Anthropology and Medicine, Centre for Medical Anthropology, Department of Psychiatry, University College London, 48 Riding House Street, London WIN 8AA

\section{On racism and mental illness}

Racism is an attractive explanation for the increased rates of psychotic lliness in AfricanCaribbeans in the UK. It has effects on physical, social and psychological environment (Williams, 1998). Its effects cross generations (Laviest, 1993: David \& Collins, 1997). It compounds the effects of gender and social class (Lillie-Blanton \& Laviest, 1996).
The experience of racism has been shown to produce pathophysiological changes acutely and is linked to a number of chronic physical illnesses (Laviest, 1996). Its influence on the perception of self and the perception of community may affect an individual's self-esteem, their ability to live a healthy lifestyle and to support others in a health promoting life-style. It may have a deleterious effect on the structures of minority communities and society as a whole (Wallace et al, 1996; Kennedy et al, 1998).

The US literature on the effects of racism on mental health is more robust than that of the UK. Studies there have not linked racism aetiologically to psychotic illness. Parker \& Kleiner (1996) have demonstrated a relationship between thwarted aspirations and psychological stress in African-Americans. More recently, the persistent, prolonged struggle and failure to overcome difficulties of blocked opportunities (John Henryism), has been linked to a decrease in psychological well-being-though not as yet to operationally defined mental ill-health (James, 1994). A discrepancy between occupational status and an ability to maintain the appearances of a successful lifestyle has been linked to depression in young African-Americans and a link between internalised racial stereotypes and depression and alcohol misuse has been described (Neighbors et al, 1996; WilliamsMorris, 1996).

Racism has community and societal meanings and correlates. Frustration and disillusionment of individuals could lead to alternative economies and lifestyles which undermine the family and are associated with low social cohesion (Wallace et al, 1996). Reduced social buffers and social disorganisation are linked to poorer mental health (Taylor et al, 1991).

The links between racism, identity and psychological development in children is a current area of interest but associations between these factors and physical and mental illness have yet to be assessed (Williams-Morris, 1996).

So what of roast breadfruit psychosis (Hickling \& Hutchinson, 1999)? There is little doubt that racism is an important stress producing factor in the UK. However, that the identity problems it fosters could not only produce psychosis but would be reflected in psychotic symptomatology remains to be proved. Why identity problems would be linked to affective disorders and substance misuse in victims of racism in the US (Neighbors, 1996) but psychosis in only one ethnic minority group in the UK would need to be explained.

Detailed study and documentation is needed if such an illness category is to be entertained, and a proper evaluation of any treatment modality would need to be undertaken before it is made widely available. 
I have little doubt that racism, in its broadest sense, is one of a number of social risk factors for mental illness. The problem that researchers have had to date is unravelling its myriad effects. But, in the era of evidence-based medicine, that is the challenge we have to face if we are to move towards therapeutic and policy interventions which will improve the lives of minority communities in the UK.

DAvid R., Counss, J. W., Jr (1997) Differing birth weight among infants born of US born blacks. African born blacks and US born whites. New England Joumal of Medicine. 357, 1209-1214.

Hickung, F. W. \& HuTCHINSON, G. (1999) Roast breadfruit psychosis: a consequence of disturbed racial identifications in African-Caribbeans. Psychiatric Bulletin. 23, 132-134.

JAMES, A. (1994) John Henrylsm and the health of African-Americans. Culture Medicine and Psychiatry. 18. $163-182$

KENNEDY, B., KAWACHI, I., LOCHNER K. (1998) Disrespect and black mortality. Ethnicty and Disease, 7, 207-214.

LAVIEST, T. (1993) Segregation, poverty, empowerment, health consequences for African-Americans. Mulbank Memorial Fund. 1. 1.

- (1996) Why we should continue to study race . . but do a better Job: an essay on race, racism and health Ethnictty and Disease, 6, 21-29.

LILEE-BLANTON. M. \& LAVIEST. T. (1996) Race ethnicity, the social environment and health. Social Science and Medicine, 43, 83-91.

Neighbors, H. W., Jackson, J. S., Broman, C., et al (1996) Racism and the mental health of African-Americans: the role of self and system blame. Ethnicity and Disease. 6. 167-175.

PARKER, S. \& KLEINER, R. (1996) Mental IIness in the Urban Negro Community. New York: Free Press.

TAYLOR, J., HENDERSON, D. \& JACKSON, B. B. (1991) A holistic model for understanding and predicting depressive symptoms in African-American women. Joumal of Community Psychology. 19, 306-320.

WALLACE, R. THOMPSON FULULOVE, M. \& FUSHER, A.J. (1996) AIDS, violence and behavioral coding: information theory, risk behavior and dynamic process on core-group sociogeographic networks. Soctal Sctence and Medictne, 48, 339-352.

WuunMs, D. (1996) Racism and health: a research agenda. Ethrictty and Disease, 6, 1-6.

WILUAMS-MORRIS, R. S. (1996) Racism and children's health: issues in development. Ethnicty and Disease. 6. 69-81.

Kwame McKenzie, Clinical Lecturer, Department of Psychological Medicine, Institute of Psychiatry. De Crespigny Park, London SE5 8AF

\section{Colluding with the illusion of race}

The central case which Hickling \& Hutchinson (1999) are making, namely the idea that Black people from the Caribbean are vulnerable to racial identity confusion, was discussed in detail in Frantz Fanon's (1952) Black Faces, White Masks. Fanon's point was that the Black Caribbean historical experience of slavery and colonialism produced a particular kind of psy- chopathology. He argued that in the historical confrontation of the Black person and the White person a dialectic was inaugurated in which the Black person perceived himself as less worthy. less human, as essentially inferior. This selfexperience already existed in the Black person growing up in the Caribbean but was exacerbated when the Black person travelled to Europe.

The problem with Fanon's analysis, as with Hickling \& Hutchinson's acceptance of his general conclusions, is his collusion with the illusion of race. There was a definite, if tacit, endorsement of the classification of human beings solely on the basis of skin colour into distinct categories as if this feature spoke to something more fundamental or essential about human beings. As Kwame Appiah (1992) put it: "In a sense, trying to classify people into a few races is like trying to classify books in a library: you may use a single property - size, say - but you will get a useless classification, or you may use a more complex system of interconnected criteria, and then you will get a good deal of arbitrariness. No one - not even the most compulsive librarian! - thinks that book classification reflects deep facts about books". The error is to argue from the gross difference in skin colour to subtle differences in temperament and attitude, and to assume that this reflects a deep fact about how we are made.

In putting forward the idea of a 'roast breadfruit syndrome' in which Hickling \& Hutchinson claim Black-skinned people see and identify themselves from a White and eurocentric perspective, that is, in which Black people think themselves White and in characterising this syndrome as being made up of an overwhelming desire for acceptance accompanied by feelings of shame of one's indigenous culture, rejection of one's indigenous language and manners and attempting to alter one's skin colour. Hickling \& Hutchinson have yet to describe in clear and unambiguous terms what this would mean in practice. What does it mean to think oneself as White? Is this a matter of actually believing oneself White when one's skin is demonstrably Black? Or is this a shorthand for saying that a Black person who happens to value highly the art of Shakespeare or Beethoven is thinking himself as White? What does the reference to indigenous culture mean in this context? Is the indigenous culture of a second generation African-Caribbean person who normally resides in Birmingham and who has never visited the Caribbean, English or Caribbean? In any case is any culture purely indigenous? Hickling \& Hutchinson want to argue that altering one's skin colour is a marker of pathology. Is this also the case for White people who fastidiously tan themselves or is it only a marker of pathology in Black people and if so, why should it be so regarded? In setting 